\title{
In Forming Software: Systems, Structuralism, Demythification ${ }^{*}$
}

\begin{abstract}
En relación a Software: Sistemas, Estructuralismo, Desmitificación *
\end{abstract}

\author{
Dr. Edward A. Shanken
}

Visiting Associate Professor (University of Washington)

- Artículo invitado -

Fecha de recepción: 28 de diciembre de 2013

Fecha de revisión: 27 de enero de 2014

Para citar este artículo: Shanken, E. A. (2014): In Forming Software:

Systems, Structuralism, Demythification, Icono 14, volumen (12), pp. 9-28. doi: $10.7195 /$ ri14.v12i2.726 


\section{Abstract}

In the mid-1960s, Marshall McLuhan prophesied that electronic media were creating an increasingly interconnected global village. Such pronouncements popularized the idea that the era of machine-age technology was drawing to a close, ushering in a new era of information technology. This shift finds parallels in a wave of major art performances and exhibitions between 1966-1970, including nine evenings: theatre and engineering at the New York Armory, spearheaded by Robert Rauschenberg, Billy Klüver, and Robert Whitman in 1966; The Machine: As Seen at the End of the Mechanical Age, curated by Pontus Hultén at the Museum of Modern Art in New York (MOMA) in 1968; Cybernetic Serendipity, curated by Jasia Reichardt at the Institute of Contemporary Art in London in 1968; and Software, Information Technology: Its New Meaning for Art, curated by Jack Burnham at the Jewish Museum in New York.

Key Words: Media art - Comunication - Structuralism

\section{Resumen}

A mediados de la década de los sesenta, Marshall McLuhan profetizó que los medios de comunicación electrónicos estaban creando una aldea global cada vez más interconectada. Este tipo de declaraciones contribuyeron a popularizar la idea de que la era de la tecnología mecánica se acerca a su fin, marcando el comienzo de la nueva era de la tecnología de la información. Este cambio encuentra ciertos paralelismos en la aparición de una serie de importantes performances y exposiciones entre 1966-1970, incluyendo nueve veladas: teatro e ingeniería en el New York Armory, encabezado por Robert Rauschenberg, Billy Klüver, y Robert Whitman, en 1966; The Machines As Seen at the End of the Mechanical Age, comisariada por Pontus Hultén en el Museum of Modern Art de Nueva York (MOMA), en 1968; Cybernetic Serendipity, comisariada por Jasia Reichardt en el Institute of Contemporary Art de Londres, en 1968; y Software, Information Tecnhology: Its New Meaning for Art, comisariada por Jack Burnham en el Jewish Musem de Nueva York.

Palabras clave: Arte Multimedia - Comunicación - Estructuralismo

ICONO14 | Año 2014 Volumen 12 N² 2 | ISSN: 1697-8293 | DOI: ri14.v12i2.726 


\section{Introduction}

In the mid-1960s, Marshall McLuhan prophesied that electronic media were creating an increasingly interconnected global village. Such pronouncements popularized the idea that the era of machine-age technology was drawing to a close, ushering in a new era of information technology. This shift finds parallels in a wave of major art performances and exhibitions between 1966-1970, including nine evenings: theatre and engineering at the New York Armory, spearheaded by Robert Rauschenberg, Billy Klüver, and Robert Whitman in 1966; The Machine: As Seen at the End of the Mechanical Age, curated by Pontus Hulten at the Museum of Modern Art in New York (MOMA) in 1968; Cybernetic Serendipity, curated by Jasia Reichardt at the Institute of Contemporary Art in London in 1968; and Software, Information Technology: Its New Meaning for Art, curated by Jack Burnham at the Jewish Museum in New York.

Hultén' simultaneously nostalgic and futuristic exhibition on art and machines included work ranging from Leonardo da Vinci's sixteenth-century drawings of flying machines to contemporary artist-engineer collaborations selected through a competition organized by Experiments in Art and Technology, Inc. (E.A.T.). E.A.T. had emerged out of the enthusiasm generated by the nine evenings, a series of performances developed through collaborations between artists and engineers. E.A.T. also lent its expertise to engineering a multimedia extravaganza designed for the Pepsi Pavilion at the Osaka World's Fair in 1970. Simultaneously, the American Pavilion at Osaka included an exhibition of collaborative projects between artists and industry that were produced under the aegis of the Art and Technology (A\&T) Program at the Los Angeles County Museum of Art. Ambitious as they were, few of the celebrated artist-engineer collaborations of this period focused on the artistic use of information technologies, such as computers and telecommunications. Taking an important step in that direction, Cybernetic Serendipity was thematically centered on the relationship between computers and creativity. This show, however, remained focused on the materiality of technological apparatuses and their products, such as robotic devices and computer graphics.

DOI: ri14.v12i2.726 | ISSN: 1697-8293 | Año 2014 Volumen 12 № 2 | ICONO14 
Burnham, known primarily as an art critic and historian, pushed the exploration of the relationship between art and information technology to an unprecedented point. Software was the first major U.S. art-and-technology exhibition that attempted to utilize computers in a museum context. Software's technological ambitions were matched by Burnham's conceptually sophisticated vision, for the show drew parallels between the ephemeral programs and protocols of computer Software and the increasingly "dematerialized" forms of experimental art, which the critic interpreted, metaphorically, as functioning like information processing systems. Software included works by conceptual artists such as Les Levine, Hans Haacke and Joseph Kosuth, whose art was presented beside displays of technology including the first public exhibition of hypertext (Labyrinth, an electronic exhibition catalog designed by Ned Woodman and Ted Nelson) and a model of intelligent architecture (SEEK, a reconfigurable environment for gerbils designed by Nicholas Negroponte and the Architecture Machine Group at MIT).

\section{Jack Burnham's Concept of "Software" as a Metaphor for Art}

Software constituted a remarkable convergence of computers and experimental art practice, drawn together through systems theory and structuralism. In contrast to other art and technology exhibitions of its era, Software was predicated on the idea of "Software" as a metaphor for art, an idea suggested by artist Les Levine. Under this rubric, Burnham explored his notion of the mythic structure of art by drawing parallels between art and information technology, particularly with respect to the conceptualism and so-called dematerialization of art in the mid- to late-1960s. Software joined works of art with works of technology and exhibited them together in an art context, purposely making "no distinction between art and non-art."1 Building on ideas in his essays, "Systems Esthetics"(1968), "Real Time Systems"(1969), and "The Aesthetics of Intelligent Systems" (1969) Burnham designed Software to function as a testing ground for public interaction with "information processing systems and their devices."2 Many of the displays were interactive and based on two-way communication between the viewer and the exhibit, heralding the ethos of interactivity that became pervasive in 1990s art and consumer culture.

ICONO14 | Año 2014 Volumen 12 N² 2 | ISSN: 1697-8293 | DOI: ri14.v12i2.726 
Burnham directly interacted with Software and a state-of-the-art, time-sharing computer system at MIT's Lincoln Laboratories during a fellowship at the Center for Advanced Visual Studies in 1968-69. Reporting on that experience, he compared the brain and the computer as information processing systems and drew further analogies between information processing and conceptual art. Concluding that the artistic potential of computers was very limited at the time, his experience was more conceptual than visual, and focused on the "challenge of ... discovering a program's memory, interactive ability, and logic functions," and on " gradually... conceptualiz[ing] an entirely abstract model of the program." ${ }^{3}$ He noted, moreover, that, "a dialogue evolves between the participants - the computer program and the human subject - so that both move beyond their original state." ${ }^{4}$ Finally, he drew a parallel between this sort of two-way communication between mind and machine, and the "eventual two-way communication" that he anticipated would evolve in art as a result of computerization:

The computer's most profound aesthetic implication is that we are being forced to dismiss the classical view of art and reality which insists that man stand outside of reality in order to observe it, and, in art, requires the presence of the picture frame and the sculpture pedestal. The notion that art can be separated from its everyday environment is a cultural fixation [in other words, a mythic structure] as is the ideal of objectivity in science. It may be that the computer will negate the need for such an illusion by fusing both observer and observed, "inside" and "outside." It has already been observed that the everyday world is rapidly assuming identity with the condition of art. ${ }^{5}$

It is difficult to imagine a more concise and prophetic manifesto for contemporary new media art than this statement, written nearly four decades ago. ${ }^{6}$

Given the conceptual nature of his computing experience at MIT, Burnham conceived of Software as analogous to the aesthetic concepts and codes that underlie the formal embodiment of the actual art objects, which in turn parallel "hardware." In this regard, he interpreted "Post-Formalist Art" (his term referring to various experimental art practices) as predominantly concerned with the Software aspect 
of aesthetic production. The term, post-formalist, like the term, postmodern, asserts itself as heir to the previously dominant aesthetic ideology and identifies formalist orthodoxy as the particular feature that it strategically countermands. Software featured what would become an all-star cast of artists associated with process, performance, and various strains of conceptual art, including Vito Acconci, John Baldessari, Robert Barry, Donald Burgy, Agnes Denes, John Giorno, Hans Haacke, Douglas Huebler, Joseph Kosuth, and Les Levine. Technologists, including Nicholas Negroponte and Ted Nelson, exhibited prescient works anticipating responsive environments and hypertext, respectively. In addition, the catalog included projects not realized in the exhibition proper by Allan Kaprow, Nam June Paik, and others, adding a further degree of conceptual ephemerality a la Seth Siegelaub's "January Show."

Burnham organized Software while writing The Structure of Art (1971) and conceived of the exhibition, in part, as a concrete realization of his structuralist art theories. ${ }^{8}$ Drawing on Claude Lévi-Strauss's notion that cultural institutions are mythic structures that emerge differentially from universal principles, Burnham theorized that western art constituted a particular mythic structure. He further theorized that the primary project of conceptual art, beginning with the work of Marcel Duchamp, was to question and lay bare the mythic structure of art by demystifying it and revealing its internal logic. ${ }^{9}$

Burnham set out these ideas in his essay "Alice's Head." True to the title, he began the essay with a quotation from Lewis Carroll's Alice in Wonderland, "...'Well! I've often seen a cat without a grin', thought Alice, 'but a grin without a cat! It's the most curious thing I ever saw in all my life!'"10 Burnham's reference suggested that, like a grin without a cat, a work of conceptual art was all but devoid of the material trappings of paint or marble traditionally associated with art objects. The artistic strategy of dematerialization was, of course, a prominent aesthetic tendency in the 1960s, identified and popularized by Lucy Lippard and John Chandler in their influential article, "The Dematerialization of Art" in Art International (February 1968). Similarly, Burnham conceived of "Software" as parallel to the dematerialized aesthetic principles, concepts, or programs that underlie the formal embodiment of the actual art objects, which in turn parallel "hardware." Deeply

ICONO14 | Año 2014 Volumen 12 N² 2 | ISSN: 1697-8293 | DOI: ri14.v12i2.726 
influenced by systems theory, Burnham recognized that "hardware and Software mutually affect and interact, determining each other's nature for a given problem. ${ }^{11}$ He proposed that Software "remove the traditional hardware props of art" and he developed an expansive notion of artistic media with "Software potential," including radio, telephone, photocopying, teletype, and television, all of which were included in the exhibition..$^{12}$ He later described Software as "an attempt to produce aesthetic sensations without the intervening 'object,' in fact, to exacerbate the conflict or sense of aesthetic tension by placing works in mundane, nonart formats." ${ }^{13}$

Burnham's use of the term "aesthetic" offers further insight into his ambitions for Software. In the context of his structuralist theory, "aesthetic sensations" and "aesthetic tensions" would constitute individual responses to works of both art and non-art placed within an art context, mediated by socially inscribed rules and expectations. Such rules and expectations can be thought of as a form of programming or social Software. In other words, viewers' programmed expectations of and responses to art are brought to bear upon non-art, while their programmed expectations of and responses to non-art are brought to bear upon art. Software sought to apply pressure to the disjunctions between the socially programmed modalities of art and non-art in order to create tension between them and thereby reveal their mythic structures.

Burnham's curatorial selections were remarkably in tune with the most advanced currents emerging in both art and technology. Many of the works anticipated and participated in important trends in intellectual and cultural history born at that time, including conceptual art, performance, video, new media, networking, hypertext, and interactivity. Quoting McLuhan, Burnham claimed that such work demonstrated a significant shift from the "isolation and domination of society by the visual sense" defined and limited by one-point perspective, to a way of thinking about the world based on the interactive feedback of information amongst systems and their components in global fields, in which there is "no logical separation between the mind of the perceiver and the environment." 14 The following discussion focuses on the work of three prominent artists whose contributions to Software demonstrate the exhibition's conceptual and metaphorical richness.

DOI: ri14.v12i2.726 | ISSN: 1697-8293 | Año 2014 Volumen 12 № 2 | ICONO14 


\section{Art as Software: Levine, Haacke, Kosuth}

In the late 1960s, Les Levine was at the forefront of experimentation with using the interactive feedback of information systems to interrogate the boundaries between artist, viewer, and environment. He was represented in Software by three pieces, including "Systems Burn-Off X Residual Software" (1969). The original installation at the Phyllis Kind Gallery in Chicago was comprised of 1000 copies of each of 31 photographs taken by Levine at the March, 1969 opening of the highly publicized "Earth Works" exhibition in Ithaca, New York. Numerous New York critics and the media had been bused upstate for the event. Most of the 31,000 photographs, which documented the media-event were "randomly distributed on the floor and covered with jello; some were stuck to the wall with chewing gum; the rest were for sale." ${ }^{\prime 16}$

In the Software exhibition catalog, Levine wrote a statement outlining his concept of Software and its relationship to art; indeed, it was he who suggested the title of the exhibition to Burnham. Levine's statement emphasized his belief that the proliferation of mass media was changing knowledge into a second-hand mental experience of simulations and representations - i.e. Software - as opposed to first-hand, direct, corporeal experiences of actual objects, places and events - i.e. hardware.

All activities which have no connection with object or material mass are the result of Software. Images themselves are hardware. Information about these images is Software... In many cases an object is of much less value than the Software concerning the object. The object is the end of a system. The Software is an open continuing system. The experience of seeing something first hand is no longer of value in a Software controlled society, as anything seen through the media carries just as much energy as first hand experience...The fact that we can confront them mentally through electronics is sufficient for us to know that they exist... In the same way, most of the art that is produced today ends up as information about art. ${ }^{17}$

ICONO14 | Año 2014 Volumen 12 Nº 2 | ISSN: 1697-8293 | DOI: ri14.v12i2.726 
Levine conceived of the 31,000 individual photos as the residual effects or "burn-off" of the information system he created - as the material manifestation of Software. In other words, "Systems Burn-Off" was an artwork that produced information (Software) about the information produced and disseminated by the media (Software) about art objects (hardware). It functioned as a meta-critique of the systematic process by which art objects (hardware) become transformed by the media into information about art objects (Software). Whereas he stated that most art "ends up as information about art," "Systems Burn-Off" was art as information about information about art, adding a level of complexity and reflexivity onto that cycle of transformations in media culture. ${ }^{18}$

"Systems Burn-0ff" can be related to Levine's interactive video installations, such as "Iris" (1968) and "Contact: A Cybernetic Sculpture" (1969). In these works video cameras captured various images of the viewer(s), which were fed back, often with time-delays or other distortions, onto a bank of monitors. As Levine noted, "'Iris' ... turns the viewer into information ... 'Contact' is a system that synthesizes man with his technology... the people are the software."19 While these works demanded the direct, corporeal experience of the participant, it was the experience of seeing oneself as information - as transformed into Software that was of primary concern to the artist:

When you look at the TV screen and see yourself on it, you don't see yourself as real flesh, but as an image of the body, as an image of the self. So it's more representative, not of body, but of appearance - how you represent, how you are represented, how you appear. I don't think those works had the capability to have any of the real bodily nature that the body really has... It was a transformative system that projected the concept of the image into some other zone. ${ }^{20}$

In this regard, Levine provocatively has noted that, "Simulation is more real than reality. Reality is an over-rated hierarchy." 21 For Levine, like other experimental artists working at the intersection of Conceptual Art and Art and Technology, the particular visual manifestation of the artwork as an object was secondary to the expression of an idea that becomes reality by simulating it. 
Like Levine, Haacke utilized technology and mass media in work that is fundamentally conceptual in nature but contributes to the discourses of multiple artistic tendencies. Perhaps best known for his politically charged critiques of power relations between individuals, art institutions, industry, the military, and government, Haacke's work in the early 1960s evolved from kinetic sculpture. He considered himself a "sort of junior partner" of the German-based Zero group ${ }^{22}$ and was included in a number of key Nouvelle Tendence exhibitions. ${ }^{23}$ The use of reductive forms and industrial materials in works of this period, such as his Condensation Boxes, can be compared with Minimal Art. But they also possessed kinetic elements and constitute dynamic systems that harness and reveal natural phenomena, which allied them with art and technology, process, earth art, and Arte Povera.

Haacke contributed two pieces to Software: "Visitor's Profile" and "News." Both works were part of the artist's "Real Time Systems" series, which was inspired in part by conversations with Burnham, a close friend since 1962, who introduced the artist to the idea of open biological systems developed by Ludwig Von Bertalanffy, and to Norbert Wiener's theories of cybernetics. ${ }^{24}$ Burnham's article, "Real Time Systems" differentiated between "ideal time" and "real time" with respect to art. ${ }^{25}$ In ideal time, the aesthetic contemplation of beauty occurs in theoretical isolation from the temporal contingencies of value, while in real time value accrues on the basis of an immediate, interactive and necessarily contingent exchange of information. "News" incorporated several Teletype machines that delivered a perpetual flow of real-time information about local, national, and international events, which was printed out on continuous rolls of paper that lay haphazardly on the floor, thus becoming aesthetic objects in ideal time. Although derived from a very different conceptual framework, this work visually resembles the postminimalist "scatter" pieces of Robert Morris, Richard Serra, Barry Le Va, and others, in which materials such as felt, lead, and rubber were unrolled or scattered in haphazard configurations in a gallery space.

In his discussion of real time systems, Burnham referred to a piece (likely "Visitor's Profile" for Software) that Haacke was planning "for a museum" that would produce a "steady output of statistical information about visitors involving a small processor-controlled computer and a display device." ${ }^{26}$ This computerized

ICONO14 | Año 2014 Volumen 12 N² | ISSN: 1697-8293 | DOI: ri14.v12i2.726 
version of "Visitor's Profile" was obviously more technologically sophisticated than the manual versions exhibited at the Howard Wise Gallery in 1969 and at the Information exhibition in 1970. But it was also far more complex in the variety of politically provocative questions it posed and the instantaneous, statistical compilation of its results. The questionnaire was almost identical to the version Haacke proposed for his canceled solo exhibition at the Guggenheim Museum in 1971. ${ }^{27}$ The installation was comprised of a tele-type terminal with a monitor that was connected to a time-sharing computer. The computer was programmed to cross-tabulate demographic information about the museum audience (age, sex, education, and so on) with their opinions on a variety of subjects, ranging from "Should the use of marijuana be legalized, lightly or severely punished?" to "Assuming you were Indochinese, would you sympathize with the present Saigon regime?" Whereas the statistical data from the other versions of "Visitor's Profile" were tabulated on a daily basis, Haacke noted in the Software catalog that:

The processing speed of the computer makes it possible that at any given time the statistical evaluation of all answers is up to date and available. The constantly changing data is projected onto a large screen, so that it is accessible to a great number of people. Based on their own information a statistical profile of the exhibition's visitors emerges. ${ }^{28}$

On the technological component of the artist's proposed museum piece, Burnham wrote, "Two years ago Haacke would have balked at using this kind of technology; today, working more closely with events, it becomes a necessity. ${ }^{29}$ Haacke amplified this statement, stressing the importance of using whatever means are necessary to respond systematically to social exigencies and an expanding informational field:

The artist's business requires his involvement with practically everything ... It would be bypassing the issue to say that the artist's business is how to work with this and that material ... and that the rest should be left to other professions ... The total scope of information he receives everyday is of concern. An artist is not an isolated system ... he has to continuously interact with the world around him... ${ }^{30}$ 
It must be noted that, like several other works in the exhibition, the Software version of "Visitor's Profile" initially did not work. Ironically, this failure appears to be due to Software problems that rendered inoperable the DEC PDP 9 time-sharing computer on loan to the Jewish Museum. Although Burnham blamed the programmer, rumors circulated ranging from sabotage to a custodian accidentally causing the computer to malfunction. Technical difficulties had beset many major art and technology exhibitions. The Smithsonian Institute decided against exhibiting $\mathrm{Cy}$ bernetic Serendipity, which already had been shipped to Washington, D.C., when the projected technical maintenance costs for the show substantially exceeded its budget. The Smithsonian had planned to exhibit Software as well but later declined.

Like Levine's Systems Burn-Off, Kosuth "unplugged" contribution to Software can be interpreted as corresponding to a technological model of information processing. His "Seventh Investigation (Art as Idea as Idea) Proposition One" (1970) included the same text in various international contexts: a billboard in English and Chinese in the Chinatown neighborhood of lower Manhattan, an advertisement in The Daily World, and a banner in Turin (in Italian, which was simultaneously on display at the Museum of Modern Art's Information exhibition). The English billboard text was comprised of a set of six propositions:

1. to assume a mental set voluntarily.

2. to shift voluntarily from one aspect of the situation to another.

3. to keep in mind simultaneously various aspects.

4. to grasp the essential of a given whole; to break up a given whole into parts and to isolate them voluntarily.

5. to generalize; to abstract common properties; to plan ahead ideationally; to assume an attitude toward the 'mere possible' and to think or perform symbolically.

6. to detach our ego from the outer world. ${ }^{31}$

Kosuth's statement in the Software catalog emphasized his intention that the work not be able to be reduced to a mental image, but that it exist as information free of any iconography. 
The elements I use in my propositions consist of information. The groups of information types exist often as 'sets' with these sets coupling out in such a manner that an iconic grasp is very difficult, if not impossible. Yet the structure of this set coupling is not the 'art'. The art consists of my action of placing this activity (investigation) in an art context, (i.e. art as idea as idea). ${ }^{32}$

In the context of Software, Kosuth's "Seventh Investigation" lends itself to an interpretation based on the exhibition's underlying metaphor of art as an information processing system and the parallel Burnham drew between how computer Software controls the hardware that runs it and how information directs the activity of the human mind. In this regard, Kosuth's propositions operate like instructions in the mind of the viewer. But whereas computer Software has an instrumental relationship with respect to coordinating the operation of hardware, the artist's propositions function as meta-analyses of the phenomenological and linguistic components of meaning. In other words, they demand that the viewer examine the process of processing information, while in the process of doing so.

Though Kosuth did not draw on computer models of information processing, his investigations follow a logic that shares affinities with that model, while at the same time demanding a self-reflexivity that goes beyond it. Kosuth's propositions required viewers to investigate the cognitive functioning of their own minds with respect to the processing of information, the creation of meaning, and the experience of consciousness. Taking a Wittgensteinian approach, the "Seventh Investigation" interrogated how the "language game" of art functioned in a larger cultural framework. This critical attitude can be seen as constitutive of the formation of society in the Information Age in general, and in the shift from an Industrial to Post-Industrial economic base. Here semantic meaning and material value are not embedded in objects, institutions, or individuals, so much as they are abstracted in the production, manipulation, and distribution of signs. 


\section{Magister Ludi or Dissolving into Comprehension}

A further abiding metaphor in Burnham's concept for Software was Marcel Duchamp's Large Glass, 1915-22, which served as an architectural model for the actual installation. Burnham described the relationship of Software to Duchamp's magnum opus in a 1970 interview with Willoughby Sharp. Iconographically, he explained, the Large Glass,

has a lot of machines in the lower section - scissors, grinders, gliders, etc... it represents the patriarchal element, the elements of reason, progress, male dominance. The top of [it] is the female component: intuition, love, internal consistency, art, beauty, and myth itself. ${ }^{35}$

Burnham claimed that "Duchamp was trying to establish that artists, in their lust to produce art, to ravish art, are going to slowly undress [it] until there's nothing left, and then art is over." He then went on to reveal Software's organizational logic:

As a kind of personal joke... I tried to recreate the same relationships in Software. I've produced two floors of computers and experiments. Then upstairs on the third floor, conceptual art with Burgy, Huebler, Kosuth, and others, which to my mind represents the last intelligent gasp of the art impulse.

Burnham's point, following his interpretation of Duchamp, was not that art was dead, or dying, or about to dissolve into nothingness. Rather, he believed that art was "dissolving into comprehension." He claimed that conceptual art was playing an important role in that process, by "feeding off the logical structure of art itself..., taking a piece of information and reproducing it as both a signified and a signifier." In other words, such work explicitly identified the signifying codes that define the mythic structure of art. Instead of simply obeying or transgressing those codes, it appropriated them as motifs, as signifiers, thereby demystifying the conventions by which meaning and value have been produced in art.

ICONO14 | Año 2014 Volumen 12 N² 2 | ISSN: 1697-8293 | DOI: ri14.v12i2.726 
Technology in art, for Burnham, ultimately was meaningful only to the extent it contributed to stripping away signifiers to reveal the mythic structure of art. In this regard, Burnham became very critical of the role of emerging technology in art. ${ }^{36}$ Having lost faith in its ability to contribute in a meaningful way to the signifying system that he believed to mediate the mythic structure of western art, in Software he purposely joined the nearly absent forms of conceptual art with the mechanical forms of technological non-art to "exacerbate the conflict or sense of aesthetic tension" between them. ${ }^{37}$ Given his interpretation of Duchamp, such a gesture also can be seen as an attempt to interrogate the categorical oppositions of art and non-art by revealing their semiotic similarity as information processing systems.

The epigraph of Burnham's The Structure of Art quotes Herman Hesse's novel The Glass Bead Game (c 1943), in which an ascetic group of intellectuals live apart from the mundane flux of everyday concerns and dedicate their creative energies to teaching and playing a highly complex associative game. Of the protagonist, Burnham wrote that ultimately,

he comes to realize that for those who practice art, it remains a 'strange and pleasant illusion.' The Master of the Game [Magister Ludi] ponders the impossibility of ever experiencing art forms as they were once experienced by those who created them.

Here the illusion of art is replaced with a higher level of creative practice, one that is not obfuscated by myth and can function in a more purely intellectual domain. For Burnham, this shift was embodied by conceptual art. If art could no longer be experienced as in the past, that loss was made up for by newly developed abilities to encounter art, modes of cognition exemplified by his account of interacting with computers and graphics Software at MIT, described above.

Sociologist Pierre Bourdieu is less sanguine about the outcome of art's demythification. At the end of "The Field of Cultural Production" (1983), he quotes 19th century poet Stéphane Mallarmé's guarded exhortation of the arts as a formulaic game of smoke and mirrors, proffered by tricksters:

DOI: ri14.v12i2.726 | ISSN: 1697-8293 | Año 2014 Volumen 12 № 2 | ICONO14 
We know, captives of an absolute formula that, indeed, there is only that which is. Forthwith to dismiss the cheat, however, on a pretext, would indict our inconsequence, denying the pleasure we want to take.... But I venerate how, by a trick, we project to a height forfended -and with thunder!- the conscious lack in us of what shines up there.

What is it for?

A game. ${ }^{38}$

In prose inspired by Mallarmé, Bourdieu elaborates:

If the pleasure of the love of art has its source in unawareness of producing the source of what produces it, then it is understandable that one might, by another willing suspension of disbelief, choose to " venerate" the authorless trickery which places the fragile fetish beyond the reach of critical lucidity. ${ }^{39}$

For Bourdieu, the art game or the field of cultural production in general is inseparable from class distinctions made on the basis of cultural capital, which is produced, sold, and acquired through a system (or amalgam of fields) whose rules must remain mysterious in order to conceal the base commercialism and status mongering that feeds it (but that must be eschewed in order for the game to be viable). As he writes, "The literary or artistic field is a field of forces, but it is also a field of struggles tending to transform or conserve this field of forces." ${ }^{40}$ The hermeticism of the field is vital to its maintenance; any attempts to demystify or transform it are typically ensnared in the indecipherability of its codes, to say nothing of a complex web of opposing positions.

Over four decades after Software, information technology has become, as Burnham envisioned, "pervasively, if not subconsciously, present in the lifestyle of [our] culture." 41 Its aesthetic implications are sufficiently manifest to play a constructive role in proposing new artistic paradigms, if not new epistemological paradigms. The pervasiveness and subconscious presence of technological apparatus, operations, and cultural practices carry with them their own mythic structures, which demand demys-

ICONO14 | Año 2014 Volumen 12 N² | ISSN: 1697-8293 | DOI: ri14.v12i2.726 
tification.

Artists engaged in emerging digital practices thus find themselves precariously teetering on two double-edged swords. Like other artists they maintain the mythic structure of art by participating in field of cultural production, which demands at least a pretense of criticality. But at the same time, producers of digital artworks also participate in the shaping the mythic structure of technology. It is unclear how artists, even if they aspire to do so, can challenge the fields of cultural and technological production in ways that undermine them rather than recapitulate them. That said, art can set itself apart from the pervasive, popular, uncritical forms of digital culture by elaborating visionary, symbolic, and metacritical practices that respond to social exigencies. In this respect, technological media may offer precisely the tools needed to reflect on the profound ways in which that very technology is deeply embedded in modes of knowledge production, perception, and interaction, and is thus inextricable from corresponding epistemological and ontological transformations. By wielding emerging digital technologies and social practices as surgical tools for critical artistic research, new media art today can, like conceptual art in the 1960s, demand new modes of cognition to encounter both art and technology. Such a metacritical method may offer artists and audiences the most advantageous opportunities to comment on and participate in the social transformations taking place in digital culture today.

\section{Notes}

* Portions of this essay were previously published in "The House That Jack Built: Jack Burnham's Concept of Software as a Metaphor for Art," in Roy Ascott, ed., Reframing Consciousness: Art and Consciousness in the Post-Biological Era (Exeter: Intellect, 1999): 156-60; "Art in the Information Age: Technology and Conceptual Art," in SIGGRAPH 2001 Electronic and Animation Catalog (New York: ACM SIGGRAPH, 2001), 8-15; "Art in the Information Age: Cybernetics, Software, Telematics, and the Conceptual Contributions of Art and Technology to Art History and Aesthetic Theory," Ph.D. diss., Duke University, 2001, and in "In Forming Software: Software, Structuralism, Dematerialization" in Douglas Kahn and Hannah Higgins, eds., Mainframe Experimentalism: Early Computing and the Foundations of the Digital Arts, (Berkeley: University of California Press, 2012): 51-60.

[1] Jack Burnham, "Notes on Art and Information Processing," In Software - Information Technology: Its New Meaning for Art, ed. Judith Root Burnham, (New York: Jewish Museum, 1970): 10 .

DOI: ri14.v12i2.726 | ISSN: 1697-8293 | Año 2014 Volumen 12 № 2 | ICONO14 
[2] Ibid.

[3] Jack Burnham, "The Aesthetics of Intelligent Systems" (1969), in Edward Fry, ed., On the Future of Art, (New York: The Viking Press, 1970)" 119.

[4] Published as Jack Burnham, "The Aesthetics of Intelligent Systems" in Edward Fry, Intro., On the Future of Art, (New York: Viking, 1970): 119.

[5] Ibid: 103

[6] Equally prophetic statements can be found in the theoretical writings of artist Roy Ascott. See Roy Ascott, Telematic Embrace: Visionary Theories of Art, Technology, and Consciousness. Ed., Edward A. Shanken. Berkeley: University of California Press, 2003.

[7] Art dealer Siegelaub gained notoriety for mounting exhibitions, beginning in 1968, in which the exhibition catalogue was the primary, if not sole, object on display. The January Show (January 5-31, 1969) included work by Barry, Heubler, Kosuth, and Lawrence Weiner.

[8] Willoughby Sharp, “Willoughby Sharp Interviews Jack Burnham," Arts 45:2 (November, 1970): 23.

[9] See, for example, Jack Burnham, “Duchamp's Bride Stripped Bare: The Meaning of the 'Large Glass,'" Arts Magazine 46 (Mar 1972): 28-32.

[10] Jack Burnham, "Alice's Head," (1970), in Great Western Salt Works: 47.

[11] Jack Burnham, unpublished notes, dated 3/13/69. Jewish Museum archives.

[12] Jack Burnham, unpublished notes, dated June 10, 1969, Jewish Museum archives.

[13] Jack Burnham. Personal correspondence with the author, April 23, 1998.

[14] Burnham, "Alice's Head": 47.

[15] The other two works were "A.I.R." (1968-70) and "Wire Tap (1969-70). A.I.R. an acronym for "Artist In Residence" was conceived of as a live, real-time video link to Levine's studio, so that the museum audience could observe the minute-to-minute activities of the artist, which were displayed on a ring of television sets, encompassing the viewer. Due to financial limitations, the actual implementation used pre-recorded videotapes of the artist in his studio. "Wire Tap" was comprised of live telephone conversations between the artist and whoever happened to call him at the moment, played over an array of twelve $12^{\prime \prime} \times 12^{\prime \prime}$ speakers.

[16] Les Levine, artist's statement, Software: 60.

[17] Ibid: 61.

[18] This cycle of transformations does not stop here. The reproduction of imagery from "Systems Burn-Off" in the Software catalog added another level to the cycle, creating information about art as information about information about art. And my discussion of it represents information about information about art as information about information about art...

[19] Levine quoted in Gene Youngblood, Expanded Cinema. (New York: E.P. Dutton and Co., Inc, 1970): 340 .

[20] Les Levine, Telephone interview with the author, January 21, 1999. 
[21] Ibid.

[22] Hans Haacke, Interview with the author, January 2, 1999.

[23] Jack Burnham, Hans Haacke: Wind and Water Sculpture" Tri-Quarterly (Evanston: Northwestern University Press, 1967): 3.

[24] Ibid. Bertalanffy's ideas were compiled in General Systems Theory: Foundations, Development, Application, New York: George Braziller, 1968. See also, Wiener's Cybernetics: or, Control and Communication in the Animal and the Machine. Cambridge: MIT Press, 1948. Many artists were introduced to these concepts by Burnham's essay Beyond Modern Sculpture: The Effects of Science and Technology on the Sculpture of This Century, New York: George Braziller, 1968, which included references to Bertalanffy's proto-cybernetic biological theories of the 1930s, the cybernetic theories of Wiener, Stafford Beer, Ross Ashby, and Gordon Pask, as well as Claude Shannon's related principles of information theory. For more on the ongoing influence of Burnham's systems theory.

[25] Jack Burnham, "Real Time Systems" Artforum (Sept 1969): 49-55, reprinted in Great Western Salt Works: 27-38.

[26] Ibid: 30.

[27] Hans Haacke, Interview with the author, January 2, 1999.

[28] Hans Haacke, artist's statement in Software: 34.

[29] Jack Burnham, "Real Time Systems," Great Western Salt Works: 30.

[30] Hans Haacke, from a talk delivered at the Annual Meeting of the Intersocietal Color Council, April, 1968. Quoted in Jack Burnham, "Real Time Systems," Great Western Salt Works: 30-31.

[31] See Joseph Kosuth, "Seventh Investigation (Art as Idea as Idea) Proposition One" illustrated in Software: 69.

[32] Joseph Kosuth, artist's statement, Software: 68.

[33] Burnham, "The Aesthetics of Intelligent Systems."

[34] A further parallel may be drawn between the event scores of artists like George Brecht and Yoko Ono, and Kosuth's propositions, which can be interpreted as functioning like event scores for the mind.

[35] Willoughby Sharp, "Willoughby Sharp Interviews Jack Burnham," Arts 45:2 (November, 1970): 23. Subsequent quotes regarding the Large Glass and the organizational logic of Software are also from this page.

[36] While Burnham's loss of faith in art and technology can already be seen in his 1969 article "The Aesthetics of Intelligent Systems," op cit., his most explicit and antagonistic pronouncement against is in Jack Burnham, "Art and Technology: The Panacea that Failed" in Myths of Information: Technology and Postindustrial Culture, Kathleen Woodward, ed., (Madison: Coda Press, 1980); reprinted in Video Culture, John Hanhardt, ed. (New York: Visual Studies Workshop Press, 1986): 232-48.

[37] Jack Burnham, Personal correspondence with the author, April 23, 1998. 
28 | Edward A. Shanken

[38] Stéphane Mallarmé, "La musique et les lettres" (c 1895, 1945) quoted in Pierre Bourdieu, "The Field of Cultural Production, or: the Economic World Reversed" Poetics 12 (1983): 353-4.

[39] Pierre Bourdieu, "The Field of Cultural Production, or: the Economic World Reversed" Poetics 12 (1983): 353-4.

[40] Pierre Bourdieu, "The Field of Cultural Production, or: the Economic World Reversed" Poetics 12 (1983): 312.

[41] Jack Burnham, "The Aesthetics of Intelligent Systems" (1969), in Edward Fry, ed., On the Future of Art, (New York: The Viking Press, 1970): 119.

ICONO14 | Año 2014 Volumen 12 Nº 2 | ISSN: 1697-8293 | DOI: ri14.v12i2.726 